\title{
STUDI KOMPARATIF MOTIVASI BELAJAR SISWA PADA MATA PELAJARAN IPS ANTARA MOVING CLASS DENGAN KELAS MENETAP DI SMP N 1 KERAMBITAN DAN SMP N 2 TABANAN TAHUN PELAJARAN 2013/2014
}

\author{
Komang Nova Arysandhi ${ }^{1}$, Made Ary Meitriana ${ }^{2}$ \\ Jurusan Pendidikan Ekonomi \\ Universitas Pendidikan Ganesha \\ Singaraja, Indonesia
}

e-mail: nova_arysandhi@yahoo.co.id ${ }^{1}$, ary.meitriana@yahoo.co.id ${ }^{2}$

\begin{abstract}
Abstrak
Penelitian ini bertujuan untuk mengetahui (1) motivasi belajar siswa pada mata pelajaran IPS yang menggunakan penataan lingkungan belajar moving class, (2) motivasi belajar siswa pada mata pelajaran IPS yang menggunakan penataan lingkungan belajar kelas menetap, dan (3) perbedaan yang signifikan motivasi belajar siswa pada mata pelajaran IPS antara siswa yang menggunakan penataan lingkungan belajar moving class dengan penataan lingkungan belajar kelas menetap di SMP N 1 Kerambitan dan SMP N 2 Tabanan tahun pelajaran 2013/2014. Penelitian ini menggunakan pendekatan kuantitatif dengan metode komparatif. Data dikumpulkan dengan metode dokumentasi dan kuesioner. Metode analisis data yang digunakan adalah analisis Independent-Sample t-test yang diolah dengan program SPSS 16.0 for windows. Hasil penelitian menunjukkan bahwa (1) rata-rata motivasi belajar siswa pada mata pelajaran IPS yang menggunakan penataan lingkungan belajar moving class sebesar 78,99 tergolong kategori tinggi, (2) rata-rata motivasi belajar siswa pada mata pelajaran IPS yang menggunakan penataan lingkungan belajar kelas menetap sebesar 63,38 tergolong cukup tinggi, dan (3) ada perbedaan yang signifikan motivasi belajar siswa pada pelajaran IPS antara siswa yang menggunakan penataan lingkungan belajar moving class dengan penataan lingkungan belajar kelas menetap di SMP N 1 Kerambitan dan SMP N 2 Tabanan tahun ajaran 2013/2014, dengan perolehan thitung $>$ ttabel $(27,527>1,967)$.
\end{abstract}

Kata kunci : kelas menetap, motivasi belajar siswa, moving class.

\begin{abstract}
This study was intended to investigate (1) students' motivation in learning IPS using moving class management, (2) students' motivation in leaning IPS using settled class management, and (3) the significance different of students' motivation in learning IPS using moving class and settled class management at junior high school "SMP N 1 Kerambitan" and at junior high school "SMP N 2 Tabanan" in academic year 2013/2014. The study used quantitative approach with comparative method. The data were collected by using documentation and questionnaire. The method analysis which was used was independent-sample t-test analysis which was analyzed by using SPSS 16.0 for windows program. The result of the study showed that (1) the average score of students' motivation in learning IPS using moving class management was 78.99 which belongs to high category, (2) the average score of students' motivation in learning IPS using settled class management was 63.38 which belongs to sufficient category, and (3) there were significance different of students' motivation in learning IPS using moving class and settled class management at SMP N 1 Kerambitan and SMP N 2 Tabanan in academic year 2013/2014, with (27.527>1.967).
\end{abstract}

Key words: settled class, students' motivation in learning, moving class. 


\section{PENDAHULUAN}

Lembaga pendidikan di tingkat SD, SMP, SMA dan sederajat setiap akhir tahun pelajaran melaksanakan sistem kenaikan kelas. Pada awal tahun pelajaran baru setiap sekolah memiliki penataan lingkungan belajar yang berbeda-beda sesuai dengan tujuan yang ingin dicapai dalam melaksanakan proses pendidikan. Dalam PP No 17 Tahun 2010 Bab I menjelaskan mengenai pengelolaan dan penyelenggaraan pendidikan. Sekolah diberikan wewenang dalam mengambil kebijaksanaan untuk menata lingkungan belajar agar proses pendidikan dapat berlangsung sesuai dengan tujuan pendidikan. Penataan lingkungan belajar pada setiap sekolah berbeda, antara lain menggunakan moving class maupun kelas menetap sesuai dengan kebijaksanaan yang diterapkan oleh masing-masing sekolah.

Moving class merupakan penataan lingkungan belajar yang siswanya berpindah-pindah kelas pada tiap awal tahun pelajaran sesuai dengan kemampuan yang dimilikinya dilihat dari hasil belajar siswa (nilai raport) tiap semesternya (Ihsan, 2010). Moving class bertujuan agar siswa dapat meningkatkan kosentrasi belajar serta menghindari kejenuhan belajar dalam kelas dengan teman yang sama sepanjang hari. Diharapkan dengan cara moving class siswa akan lebih bersemangat dalam belajar, karena beberapa siswa akan berpindah ke kelas yang baru pada awal tahun pelajaran sesuai kemsampuan siswa.

Kelas menetap merupakan penataan lingkungan belajar yang siswanya tetap tinggal dengan teman yang sama dari kelas VII sampai kelas IX dalam kelas yang sama (Ihsan, 2010). Di dalam kelas menetap akan dapat menumbuhkan rasa kekeluargaan dari siswa yang berada dalam kelas dikarenakan mereka tetap bersama-sama dari awal hingga akhir di kelas yang sama. Di dalam kelas menetap ini akan dibagi siswa yang pandai dengan siswa yang kurang pandai, jadi di setiap kelas akan merata siswa yang pandai dengan siswa yang kurang pandai agar siswa yang kurang pandai dapat termotivasi untuk belajar dari siswa yang pandai.
Moving class dan kelas menetap lingkungan belajar dan sirkulasi pembelajaran yang diciptakan oleh sekolah untuk membangkitkan motivasi belajar siswa. Sardiman (2006:75) "motivasi belajar merupakan serangkaian usaha untuk menyediakan kondisi-kondisi tertentu, sehingga seseorang mau dan ingin melakukan sesuatu, dan bila ia tidak suka, maka akan berusaha untuk meniadakan atau mengelak perasaan tidak suka itu". Motivasi belajar dapat timbul karena faktor intrinsik, berupa hasrat dan keinginan berhasil dan dorongan kebutuhan belajar, harapan dan cita-cita. Sedangkan faktor ekstrinsiknya adalah adanya penghargaan, lingkungan belajar yang kondusif, dan kegiatan belajar yang menarik.

Dari perbedaan penataan lingkungan belajar tersebut (moving class dan kelas menetap) peneliti tertarik untuk meneliti apakah terdapat perbedaan motivasi belajar yang signifikan pada mata pelajaran IPS akibat dari adanya pemberlakuan pengaturan kelas yang berbeda antara moving class dengan kelas menetap.

Motivasi dan belajar merupakan dua hal yang saling berhubungan dan mempengaruhi. Menurut Nasution yang dikutip oleh Moekijat (2002), motivasi berasal dari suku kata "motif" yang diartikan sebagai daya upaya yang mendorong seseorang untuk melakukan sesuatu. menurut Mc. Donald yang dikutip oleh Sardiman (2006:73), "motivasi adalah perubahan energi dalam diri seseorang yang ditandai dengan munculnya "feeling" dan didahului dengan tanggapan adanya tujuan". Menurut Alisuf Sabri (1993:39), "motivasi adalah segala yang menjadi pendorong tingkah laku yang menuntut/mendorong orang untuk memenuhi suatu kebutuhan dan sesuatu yang dijadikan motivasi itu merupakan suatu keputusan yang telah ditetapkan individu sebagai suatu kebutuhan/tujuan yang nyata ingin dicapai". Berdasarkan difinisi motivasi dapat disimpulkan bahwa motivasi merupakan dorongan dasar atau kemauan yang menggerakan seseorang melakukan sesuatu untuk mencapai tujuan 
tertentu sebagai perubahan tingkah laku seseorang berdasarkan pengalaman yang diperolehnya.

Menurut Muhibbin (2004:64), "belajar adalah kegiatan yang berproses dan merupakan unsur yang sangat fundamental dalam penyelnggaraan setiap jenis dan jenjang pendidikan". Menurut Slameto (2010:2), "belajar ialah suatu proses usaha yang dilakukan seseorang untuk memperoleh suatu perubahan tingkah laku yang baru secara keseluruhan, sebagai hasil pengalamannya sendiri dalam interaksi dengan lingkungannya". Dari beberapa pendapat di atas dapat di simpulkan, belajar dapat diartikan sebagai suatu proses usaha yang dilakukan individu untuk memperoleh perubahan yang relatif menetap dalam tingkah laku baik yang dapat diamati maupun yang tidak dapat diamati secara langsung dan terjadi sebagai suatu hasil dari latihan atau pengalaman.

Jadi motivasi belajar dapat diartikan sebagai dorongan baik dari dalam diri maupun luar siswa yang memberikan arah pada kegiatan belajar, sehingga tujuan yang dikehendaki oleh subjek belajar itu dapat tercapai.

Sardiman (2006) menyatakan bahwa ada tiga fungsi dari motivasi, yaitu. (1) dorongan, mendorong seseorang untuk berbuat dalam mencapai tujuannya. (2) penentu arah perbuatan, yakni kearah tujuan yang hendak dicapai. (3) penyeleksian perbuatan sehingga perbuatan orang yang mempunyai motivasi senantiasa selektif dan tetap kearah tujuan yang ingin dicapai.

Selain memiliki fungsi sebagai pendorong, penentu arah perbuatan dan penyeleksian perbuatan, motivasi juga memiliki beberapa peranan dalam belajar. Hamzah (2008) menyatakan ada tiga peranan penting dari motivasi dalam belajar, sebagai berikut. (1) penentu penguatan belajar. (2) memperjelas tujuan belajar. (3) ketekunan belajar.

Dapat disimpulkan bahwa motivasi bukan hanya berfungsi sebagai penentu terjadinya suatu perbuatan tetapi juga merupakan penentu hasil perbuatan. Motivasi juga berperan sebagai pendorong untuk bekerja atau melakukan sesuatu perbuatan dengan sungguh-sungguh (tekun) dan selanjutnya akan menentukan hasil pekerjaannya.

Ada tidaknya motivasi seseorang individu untuk belajar sangat berpengaruh dalam proses aktivitas belajar itu sendiri. Seperti dikemukakan oleh Sardiman (2006:83) motivasi memiliki ciri-ciri sebagai berikut. (1) tekun menghadapi tugas. (2) ulet menghadapi kesulitan. (3) mewujudkan minat terhadap bermacam-macam masalah untuk orang dewasa. (4) lebih senang bekerja sendiri. (5) cepat bosan pada tugas yang rutin. (6) dapat mempertahankan pendapatnya. (7) tidak mudah melepaskan hal yang diyakini. (8) senang mencari dan memecahkan masalah soal-soal.

Dari pendapat tersebut dapat disimpulkan bahwa siswa yang memiliki motivasi tinggi dalam belajar akan menunjukkan hal-hal sebagai berikut : 1) keinginan mendalami materi, 2) ketekunan dalam mengerjakan tugas, 3) keinginan berprestasi, dan 4) keinginan untuk maju.

Dalam perkembangan selanjutnya, motivasi dapat dibedakan menjadi dua macam, yaitu motivasi yang berasal dari diri siswa yang sering disebut motivasi intrinsik dan motivasi yang berasal dari luar diri seseorang yang biasa disebut motivasi ekstrinsik.

"Motivasi intrinsik yaitu motif-motif yang menjadi aktif atau tidak memerlukan rangsangan dari luar, karena dalam diri setiap individu sudah ada dorongan untuk melakukan sesuatu" (Djamarah, 2002:115). Sedangkan menurut Dimyanti dan Mudjiono (2002:90) "motivasi intrinsik adalah motivasi yang timbul dari dalam diri pribadi individu itu sendiri tanpa adanya pengaruh dari luar individu". Dari beberapa pendapat tersebut dapat disimpulkan motivasi intrinsik adalah motivasi yang muncul dari dalam diri dengan kemauan orang itu sendiri tanpa memerlukan rangsangan dari luar.

"Motivasi ekstrinsik adalah hal dan keadaan yang datang dari luar individu siswa yang juga mendorongnya untuk melakukan kegiatan belajar" (Sumadi, 2007:152). Hal lain diungkapkan oleh Dimyanti dan Mudjiono (2002:90), "motivasi ekstrinsik adalah dorongan terhadap perilaku seseorang yang ada diluar 
perbuatan yang dilakukannya dan mendapat pengaruh atau rangsangan dari luar". Dari beberapa pendapat diatas dapat disimpulkan bahwa motivasi ekstrinsik adalah motivasi yang timbul akibat adanya dorongan, paksaan atau pengaruh dari luar sehingga dengan keadaan demikian siswa mau melakukan sesuatu atau belajar.

Menurut Sardiman (2006) ada beberapa bentuk dan cara untuk menumbuhkan motivasi belajar siswa, adapun cara tersebut adalah sebagai berikut (1) memberi angka, (2) hadiah, (3) saingan dan kompetisi, (4) ego-involementi, (5) memberikan ulangan, (6) mengetahui hasil, (7) pujian, (8) hukuman, (9) minat, (10) hasrat untuk belajar, (11) tujuan yang diakui.

Ada beberapa hal yang dapat mempengaruhi motivasi belajar siswa menurut Dimyanti dan Mudjiono (2006), yaitu (1) cita-cita dan aspirasi siswa, (2) kemampuan siswa, (3) kondisi siswa, (4) kondisi lingkungan siswa, (5) upaya guru dalam membelajarkan siswa.

Setiap sekolah memiliki kebijakan masing-masing dalam mencapai tujuan pendidikan. Sekolah mendapat wewenang untuk menata lingkungan belajar apa yang akan digunakan agar proses pendidikan dapat berlangsung sesuai dengan tujuan pendidikan. Penataan lingkungan belajar setiap sekolah berbeda, ada yang menggunakan moving class maupun kelas menetap.

Moving class merupakan penataan lingkungan belajar yang siswanya berpindah-pindah kelas pada tiap awal tahun pelajaran sesuai dengan kemampuan yang dimilikinya dilihat dari hasil belajar siswa (nilai raport) tiap semesternya (Ihsan, 2010).

Kelas menetap merupakan penataan lingkungan belajar yang dimana siswanya tetap tinggal dengan teman yang sama dari kelas VII sampai kelas IX dalam kelas yang sama (Ihsan, 2010).

Dari uraian di atas, dapat disimpulkan bahwa antara moving class dengan kelas menetap pada dasarnya merupakan penataan lingkungan belajar dan sirkulasi pembelajaran yang diciptakan oleh sekolah untuk membangkitkan motivasi belajar siswa.

\section{METODE}

Penelitian ini menggunakan pendekatan kuantitatif dengan metode komparatif yang bertujuan untuk membandingkan keberadaan suatu variabel atau lebih pada dua atau lebih sampel yang berbeda, atau pada waktu yang berbeda (Sugiyono, 2010). Metode komparatif digunakan untuk mengetahui perbedaan motivasi belajar siswa pada pelajaran IPS antara moving class dengan kelas menetap di SMP N 1 Kerambitan dan SMP N 2 Tabanan.

Subjek dalam penelitian ini adalah siswa yang bersekolah di SMP $\mathrm{N} 1$ Kerambitan dan SMP N 2 Tabanan, sedangkan objek dalam penelitian ini adalah motivasi belajar siswa pada pelajaran IPS.

Dalam penelitian ini yang menjadi populasi adalah siswa SMP Negeri 1 Kerambitan dan SMP Negeri 2 Tabanan pada tahun ajaran 2013/2014. Adapun jumlah populasi pada penelitian ini, adalah siswa SMP N 1 Kerambitan dan SMP N 2 Tabanan dapat dilihat pada tabel 1 sebagai berikut.

Tabel 1 Jumlah Keseluruhan Populasi

\begin{tabular}{cccc}
\hline No & Sekolah & Kelas & $\begin{array}{c}\text { Jumlah } \\
\text { Siswa }\end{array}$ \\
\hline \multirow{4}{*}{1} & SMP N 1 & VII & 271 siswa \\
& Kerambitan & VIII & 323 siswa \\
\cline { 1 - 2 } 2 & IX & 300 siswa \\
2 & SMP N 2 & VII & 523 siswa \\
& Tabanan & VIII & 591 siswa \\
& IX & 408 siswa \\
& Total Populasi & & 2.416 \\
& & & siswa \\
\hline
\end{tabular}

Dari tabel di atas terlihat bahwa jumlah populasi dari semua siswa SMP N 1 Kerambitan \& SMP N 2 Tabanan sebanyak 2.416 siswa. Mengingat jumlah populasi cukup banyak, maka dari jumlah populasi tersebut akan diambil sebagian untuk dijadikan sampel. Menurut Sugiyono (2009:81), "sampel adalah bagian dari jumlah dan karakteristik yang dimiliki oleh populasi tersebut", sedangkan penentuan sampel penelitian dengan teknik Proportional Stratified Random Sampling. Menurut Dantes (2012:42), "Proportional 
Stratified Random Sampling adalah cara pengambilan sampel populasi yang mempunyai anggota/unsur yang tidak homogen dan berstrata secara proporsional dari setiap elemen populasi yang dijadikan sampel dan pengambilan sampel dilakukan secara random". Dalam menentukan ukuran sampel dengan jumlah populasi 2.415 untuk taraf kesalahan 5\% jumlah sampelnya adalah 331 (Dantes,2012). Jadi dari sampel tersebut dibagi secara proporsional menurut jumlah siswa masing-masing sekolah, untuk SMP N 1 Kerambitan diambil sampel 123 siswa didapat dari persentase masing-masing sekolah (37\%) dikali jumlah sampel, sedangkan SMP N 2 Tabanan diambil sampel 208 siswa didapat dari persentase masing-masing sekolah (63\%) dikali jumlah sampel.

Setelah diketahui sampel dari setiap sekolah maka pengambilan sampel ini dilakukan secara proporsional, untuk SMP $\mathrm{N} 1$ Kerambitan sampelnya ialah 123 siswa, maka penentuan proporsional menurut Sofyan Siregar (2011) sebagai berikut.

a. Ukuran sampel untuk SMP N 1 Kerambitan $=123$

b. Proporsi sampel untuk setiap strata $=$ $123 / 894=0,137583$

c. Setiap jumlah populasi dari setiap strata dikalikan proporsi di setiap strata

d.

Jumlah sampel di SMPN 1 Kerambitan disajikan pada tabel 2 berikut.

Tabel 2 Jumlah Sampel di SMP N 1 Kerambitan Untuk Moving class

\begin{tabular}{lccccc}
\hline No & Kelas & $\begin{array}{c}\text { Populasi } \\
\text { (Orang) }\end{array}$ & Proporsi & Jumlah Sampel & Pembulatan (Orang) \\
\hline 1 & VII & 271 & 0,137583 & 37,3 & 37 \\
2 & VIII & 323 & 0,137583 & 44,6 & 45 \\
3 & IX & 300 & 0,137583 & 41,3 & 41 \\
\multicolumn{2}{l}{ Total Populasi } & 894 & & & 123 \\
\hline
\end{tabular}

Untuk SMP N 2 Tabanan sampelnya ialah 208 siswa, maka penentuan proporsional menurut Sofyan Siregar (2011: 146) diketahui :

a. Ukuran sampel $=208$ b. Proporsi sampel untuk strata = $208 / 1522=0,136662$

c. Setiap jumlah populasi dari strata dikalikan proporsi di setiap strata

Jumlah sampel di SMPN 2 Tabanan disajikan pada tabel 3 berikut.

Tabel 3. Jumlah Sampel di SMP N 2 Tabanan Untuk Kelas Menetap

\begin{tabular}{lccccc}
\hline No & Kelas & $\begin{array}{c}\text { Populasi } \\
\text { (Orang) }\end{array}$ & Proporsi & Jumlah Sampel & Pembulatan (Orang) \\
\hline 1 & VII & 523 & 0,136662 & 71,4 & 71 \\
2 & VIII & 591 & 0,136662 & 80,8 & 81 \\
3 & IX & 408 & 0,136662 & 55,8 & 56 \\
\multicolumn{2}{l}{ Total Populasi } & 1.522 & & & 208 \\
\hline
\end{tabular}

Jenis data yang digunakan dalam penelitian ini dibedakan menjadi dua yaitu data kuantitatif dan data kualitatif. Data kuantitatif berupa data yang dinyatakan dalam bentuk angka,-angka berupa skor jawaban yang diperoleh dari responden yaitu siswa SMP N 1 Kerambitan dan SMP N 2 Tabanan. Data kualitatif berupa data yang tidak dinyatakan dalam bentuk angka yang sifatnya penunjang dalam pembahasan seperti profil dari SMP N 1 kerambitan dan SMP N 2 Tabanan, dalam hal ini berupa dokumen sekolah seperti data siswa (jumlah \& nama siswa).

Berdasarkan sumber data dalam penelitian ini dibedakan menjadi dua yaitu 
data primer dan data sekunder. Data primer dalam penelitian ini adalah informasi yang dikumpulkan berdasarkan jawaban responden terhadap kuesioner motivasi belajar siswa. Data sekunder merupakan data yang diperoleh dalam bentuk dokumen-dokumen tentang SMP N 1 Kerambitan dan SMP N 2 Tabanan, berupa jumlah dan nama-nama siswa. Pengumpulan data dalam penelitian ini menggunakan (1) Metode dokumentasi, yaitu Dokumentasi digunakan untuk memperoleh data yang dilakukan dengan mempelajari catatancatatan, dokumen-dokumen yang ada, berupa data siswa (jumlah \& nama-nama siswa). (2) Metode Kuesioner, yaitu digunakan untuk memperoleh data yang dilakukan dengan memberikan rangkaian pernyataan kepada responden (siswa) untuk dijawab, terutama pernyataan yang berkaitan dengan motivasi belajar siswa terhadap pelajaran IPS antara siswa moving class di SMP N 1 Kerambitan dan siswa kelas menetap di SMP $\mathrm{N} 2$ Tabanan.

Analisis yang digunakan dalam penelitian ini adalah Analisis Statistik Komperatif, analisis ini dimaksudkan untuk menguji apakah ada perbedaan yang signifikan antara motivasi belajar siswa pada pelajaran IPS antara siswa moving class di SMP N 1 Kerambitan dan kelas menetap di SMP $\mathrm{N} 2$ Tabanan. Sebagai alat yang digunakan adanya perbedaan digunakan perbedaan analisis perbandingan rata-rata (Two IndependentSample Test) dan dihitung dengan menggunakan program SPSS 16.00 for windows ( Wahyono, 2009).

Kriteria skor rata-rata motivasi belajar siswa disajikan pada tebl 4 berikut.

Tabel 4. Kriteria Skor Rata-rata Motivasi Belajar Siswa

\begin{tabular}{cl}
\hline Rentang Skor & \multicolumn{1}{c}{ Kategori } \\
\hline $79,5-95$ & Sangat Tinggi \\
$63,9-79,4$ & Tinggi \\
$48,3-63,8$ & Cukup Tinggi \\
$32,7-48,2$ & Rendah \\
$17-32,6$ & Sangat Rendah \\
\hline
\end{tabular}

\section{HASIL DAN PEMBAHASAN \\ Motivasi Belajar Siswa Pada Mata Pelajaran IPS Yang Menggunakan Penataan Lingkungan Belajar Moving class}

Berdasarkan kuesinoer yang disebar di beberapa kelas dari kelas VII-IX di SMP N 1 Kerambitan, diperoleh data motivasi belajar siswa tahun ajaran 2013/2014 dengan jumlah sampel 123 siswa pada tabel 5.
Dari Tabel 5 dapat dilihat bahwa rata-rata motivasi belajar dari siswa yang di sekolahnya menggunakan penataan lingkungan belajar moving class sebesar 78,99. Hasil tersebut menunjukkan bahwa motivasi belajar siswa pada mata pelajaran IPS yang menggunakan penataan lingkungan belajar moving class tergolong kategori tinggi.

Tabel 5 Group Statistic Motivasi Belajar Siswa Pada Mata Pelajaran IPS Yang Menggunakan Penataan Lingkungan Belajar Moving class

\begin{tabular}{llcccc}
\hline & Kelas & $\mathrm{N}$ & Mean & Std. Deviation & $\begin{array}{c}\text { Std. Error } \\
\text { Mean }\end{array}$ \\
\hline Hasil & Moving class & 123 & 78.99 & 5.061 & .456 \\
\hline
\end{tabular}




\section{Motivasi Belajar Siswa Pada Mata Pelajaran IPS Yang Menggunakan Penataan Lingkungan Belajar Kelas Menetap}

Berdasarkan kuesinoer yang disebar di beberapa kelas dari kelas VII-IX di SMP N 2 Tabanan, diperoleh data motivasi belajar siswa tahun ajaran 2013/2014 dengan jumlah sampel 208 siswa pada tabel 6.

Tabel 6 Group Statistic Motivasi Belajar Siswa Pada Mata Pelajaran IPS Yang Menggunakan Penataan Lingkungan Belajar Kelas Menetap

\begin{tabular}{llcccc}
\hline & & & & Std. Error \\
Kelas & $\mathrm{N}$ & Mean & Std. Deviation & Mean \\
\hline Hasil & Kelas Menetap & 208 & 63.38 & 4.942 & .343
\end{tabular}

Dari Tabel 6 dapat dilihat bahwa rata-rata motivasi belajar dari siswa yang di sekolahnya menggunakan penataan lingkungan belajar kelas menetap sebesar 63,38 . Hasil tersebut menunjukkan bahwa motivasi belajar siswa pada mata pelajaran IPS yang menggunakan penataan lingkungan belajar kelas menetap tergolong kategori cukup tinggi.

\section{Perbedaan Motivasi Belajar Siswa Pada} Mata Pelajaran IPS Antara Siswa Yang Menggunakan Penataan Lingkungan Belajar Moving class dengan Penataan Lingkungan Belajar Kelas Menetap

Berdasarkan rata-rata motivasi belajar siswa pada mata pelajaran IPS yang menggunakan penataan lingkungan belajar moving class diperoleh mean 78,99 dan motivasi belajar siswa pada mata pelajaran IPS yang menggunakan penataan lingkungan belajar kelas menetap diperoleh mean 63,38. Dengan demikian, dari nilai rata-rata yang diperoleh tersebut dapat ditarik kesimpulan sementara bahwa ada perbedaan tentang motivasi belajar siswa pada mata pelajaran IPS antara siswa moving class di SMP N 1 Kerambitan dan siswa kelas menetap di SMP $\mathrm{N} 2$ Tabanan. Untuk menguji signifikan perbedaan digunakan analisis uji hipotesis yaitu analisis yang dimaksudkan untuk menguji hipotesis yang diajukan dalam penelitian ini, sehingga hipotesis tersebut dapat diterima kebenarannya atau ditolak kebenarannya. Berdasarkan analisis uji Independent-Sample T-test dengan bantuan program SPSS 16.00 for windows diperoleh data sebagai berikut.

Tabel 7 Uji Independent Sample T-test

\begin{tabular}{|c|c|c|c|}
\hline & & & asil \\
\hline & & $\begin{array}{c}\text { Equal } \\
\text { variances } \\
\text { assumed }\end{array}$ & $\begin{array}{l}\text { Equal } \\
\text { variances not } \\
\text { assumed }\end{array}$ \\
\hline Levene's Test for & $\mathrm{F}$ & .242 & \\
\hline $\begin{array}{l}\text { Equality } \\
\text { Of Variances }\end{array}$ & Sig. & .623 & \\
\hline t-test for Equality of & $T$ & 27.527 & 27.358 \\
\hline Means & df & 329 & 251.268 \\
\hline & Sig (2-tailed) & .000 & .000 \\
\hline & Mean Difference & 15.612 & 15.612 \\
\hline & Std. Error Difference & .567 & .571 \\
\hline & 95\% Confidence Internal & 14.496 & 14.488 \\
\hline & $\begin{array}{l}\text { Lower } \\
\text { of the Difference } \\
\text { Upper }\end{array}$ & 16.728 & 16.736 \\
\hline
\end{tabular}


Dari tabel 7 dapat diketahui hasil uji $\mathrm{t}$ diperoleh $\mathrm{t}_{\text {hitung }}$ (equal variance assumed) adalah 27,527 sedangkan $t_{\text {tabel }}$ dengan taraf signifikan 5\% diperoleh 1,967. Ini berarti bahwa $t_{\text {hitung }}>$ dari $t_{\text {tabel }}$ $(27,527>1,967)$ maka Ha diterima, dari perbandingan tersebut ditarik kesimpulan bahwa ada perbedaan yang signifikan antara motivasi belajar siswa pada mata pelajaran IPS antara siswa yang menggunakan penataan lingkungan belajar moving class di SMP $\mathrm{N} 1$ Kerambitan dengan penataan lingkungan belajar kelas menetap di SMP $\mathrm{N} 2$ Tabanan tahun pelajaran 2013/2014.

Berdasarkan hasil penelitian dapat diketahui bahwa skor motivasi belajar siswa pada mata pelajaran IPS yang menggunakan penataan lingkungan belajar moving class di SMP N 1 Kerambitan tahun pelajaran 2013/2014 sebesar 78,99 yang berada dalam rentang 63,9 - 79,4 yang berkategori tinggi dan skor motivasi belajar siswa pada mata pelajaran IPS yang menggunakan penataan lingkungan belajar kelas menetap di SMP N 2 Tabanan tahun pelajaran $2013 / 2014$ sebesar 63,38 yang berada dalam rentang 48,3 - 63,8 yang berkategori cukup tinggi.

Pengujian hipotesis menggunakan analisis Independent Sample T-test, menunjukan bahwa ada perbedaan yang signifikan tentang motivasi belajar siswa pada mata pelajaran IPS yang menggunakan penataan lingkungan belajar moving class di SMP $\mathrm{N} 1$ Kerambitan dengan yang menggunakan penataan lingkungan belajar kelas menetap di SMP $\mathrm{N} 2$ Tabanan yang ditunjukkan dengan nilai thitung $>$ dari ttabel $(27,257>1,967)$. Perbedaan itu dilatarbelakangi oleh faktor internal dan eksternal siswa, antara lain kondisi siswa, kemampuan siswa, hasrat dan keinginan untuk berhasil, kebutuhan akan belajar, keluarga, keinginan untuk mendapat penghargaan atau pujian, cara dan kualitas guru dalam mengajar, dan lingkungan belajar yang kondusif.

Hasil penelitian ini sejalan dengan teori yang dikemukakan oleh Hamzah (2008:20) "motivasi belajar adalah dorongan internal dan eksternal pada siswa-siswa yang sedang belajar untuk mengadakan perubahan tingkah laku, pada umumnya dengan indikator atau unsur yang mendukung". Sedangkan menurut Sumadi (2007:151) "motivasi ialah keadaan internal dan eksternal organisme baik manusia ataupun hewan yang mendorongnya untuk berbuat sesuatu".

Motivasi yang berasal dari diri sendiri dan yang berasal dari luar, keduanya sangat berpengaruh pada tindakan. Dengan adanya kedua motivasi tersebut, maka seseorang dapat melakukan tindakan-tindakan atau perbuatan-perbuatan dengan baik sehingga dapat mencapai tujuan yang diharapakan. Untuk dapat belajar dengan baik di perlukan proses (penataan lingkungan belajar) dan motivasi (intrinsik atau ekstrinsik) yang baik, memberikan motivasi kepada pembelajar, berarti menggerakkan seseorang agar ia mau atau ingin melakukan sesuatu. Jadi dapat disimpulkan bahwa motivasi belajar siswa yang menggunakan penataan lingkungan belajar moving class di SMP $\mathrm{N} 1$ Kerambitan lebih baik dari penataan lingkungan belajar kelas menetap di SMP N 2 Tabanan, yaitu sebesar 78,99>63,38.

\section{SIMPULAN DAN SARAN}

Berdasarkan hasil penelitian yang dilakukan, maka dapat ditarik simpulan sebagai berikut. (1) Motivasi belajar siswa pada mata pelajaran IPS di SMP N 1 Kerambitan dengan menggunakan penataan lingkungan belajar moving class memiliki nilai rata-rata 78,99 . Hal ini menunjukkan bahwa motivasi belajar siswa pada pelajaran IPS yang menggunakan penataan lingkungan belajar moving class tergolong dalam kategori tinggi. (2) Motivasi belajar siswa pada mata pelajaran IPS di SMP N 2 Tabanan dengan menggunakan penataan lingkungan belajar kelas menetap memiliki nilai rata-rata 63,38. Hal ini menunjukkan bahwa motivasi belajar siswa pada pelajaran IPS yang menggunakan penataan lingkungan belajar kelas menetap tergolong dalam kategori cukup tinggi. (3) Ada perbedaan motivasi belajar siswa pada pelajaran IPS antara penataan lingkungan belajar moving class di SMP N 1 Kerambitan dengan 
penataan lingkungan belajar kelas menetap di SMP N 2 Tabanan. Berdasarkan hasil pengujian hipotesis penelitian diperoleh $\mathrm{t}_{\text {hitung }}$ (equalvariance assumed) 27,257 dan $t_{\text {tabel }}$ dengan taraf signifikan 5\% diperoleh 1,967. Ini berarti $t_{\text {hitung }}>\mathrm{t}_{\text {tabel }}(27,257>1,967)$. Hasil analisis Independent Sample T- test tersebut menunjukan bahwa ada perbedaan yang meyakinkan antaramotivasi belajar siswa pada pelajaran IPS di SMP N 1 Kerambitan yang menggunakan penataan lingkungan belajar moving class dengan motivasi belajar siswa pada pelajaran IPS di SMP N 2 Tabanan yang menggunakan penataan lingkungan belajar kelas menetap.

Berdasarkan temuan hasil penelitian yang telah dibahas pada bab IV dan dari penarikan simpulan di atas, dapat diajukan saran-saran sebagai berikut. (1) Bagi pihak sekolah dalam upaya meningkatkan pembelajaran yang baik diperlukan proses (penataan lingkungan belajar) yang baik, hal ini dilakukan untuk meningkatkan motivasi belajar siswa (ekstrinsik) agar siswa merasa lebih nyaman dalam belajar, lebih giat dalam belajar dan dapat meningkatkan cara belajar siswa di dalam kelas. (2) Motivasi belajar siswa SMP N 1 Kerambitan dan SMP N 2 Tabanan sudah baik dan diharapkan dapat ditingkatkan lagi, karena siswa-siswi sekolah ini memiliki semangat yang tinggi dalam pembelajaran dan memiliki rasa ingin tahu yang tinggi dalam dunia pendidikan yang dimana dapat dijadikan contoh oleh siswasiswi lainnya diberbagai sekolah baik negeri maupun swasta. (3) Bagi peneliti yang lain diharapkan dapat mengembangkan penelitian ini di masa yang akan datang, sehingga penelitian ini lebih sempurna.

\section{DAFTAR PUSTAKA}

Ahmad, Mudzakir. 1997. Psikologi Pendidikan. Bandung : Pustaka Setia.

rikunto, Suharsimi. 2006. Prosedur Penelitian (Suatu Pendekatan Praktik). Jakarta: PT Rineka Cipta.

Dantes, Nyoman. 2012. Metodologi Penelitian. Yogyakarta : C.V Andi Offset.
Dimyanti dan Mudjiono. 2002. Belajar dan Pembelajaran. Jakarta : PT. Rineka Cipta.

-------, 2006. Belajar dan Pembelajaran. Jakarta : PT. Rineka Cipta.

Djamarah, Syaiful Bahri. 2002. Psikologi Belajar. Jakarta : PT. Rineka Cipta.

Hamzah, Haji 2008. Teori Motivasi dan Pengukurannya. Jakarta : Bumi Aksara.

Ihsan, Fuad. 2010. Dasar-dasar Kependidikan. Jakarta : PT. Rineka Cipta.

Irianto, Agus. 2004. Statistik Konsep dan Aplikasinya. Jakarta : Prenada Media.

Irwanto. 1997. Psikologi Umum. Jakarta : PT. Gramedia Pustaka Utama.

Mulyasa, E. 2003. Kurikulum Berbasis Kompetensi. Bandung : Remaja Rosdakarya.

Moekijat. 2002. Dasar-dasar Motivasi. Bandung : CV. Pionir Jaya Bandung.

Nilawati, 2012. Studi Komparatif Motivasi Belajar Siswa Penduduk Asli Dengan Siswa Pendatang di SMAN 16 Siak. Tersedia pada : http://lib.unri.ac.id/skripsi/index.ph $\mathrm{p} ? \mathrm{p}=$ show_detail\&id=39198 (diakses pada 1 September 2013).

Purwanto, M. Ngalim. 1992. Psikologi Pendidikan. Bandung : PT. Remaja Rosdakarya.

Sabri, M. Alisuf. 1993. Pengantar Psikologi Umum dan Perkembangan. Jakarta : Pedoman Ilmu Jaya.

Sardiman. 2006. Interaksi dan Motivasi Belajar Mengajar. Jakarta : PT. Raja Grafindo Persada.

Sari, Erna Julia. 2010. Pengaruh Pemanfaatan Media Pembelajaran Terhadap Motivasi Belajar Siswa Kelas IX di SMP N 1 Singaraja tahun 2010. Skripsi (tidak diterbitkan). Undiksha.

Siagan, P. Sondang. 2004. Teori Motivasi dan Aplikasinya. Jakarta : PT. Asdi Mahasatya. 
Siregar, Syofian. 2010 . Statistika Deskriptif Untuk Penelitan. Jakarta: Raja Grafindo Persada.

-------, 2011 . Statistika Deskriptif Untuk Penelitan. Jakarta: Raja Grafindo Persada.

Slameto. 2010. Belajar dan Faktor-faktor yang Mempengaruhinya. PT Rineka Cipta: Jakarta.

Sugiyono. 2009. Metode Penelitian Kuantitatif Kualitatif dan $R \& D$. Álfabeta: Bandung.

2010. Metode Penelitian Kuantitatif Kualitatif dan R\&D. Álfabeta: Bandung.

Supranto. 2003. Metode Riset Aplikasinya dalam Pemasaran. Jakarta : Rineka Cipta

Sutikno, Sobry. 2007. Peran Guru dalam Membangkitkan Motivasi Belajar Siswa. Tersedia pada : www.bruderfic.or.id (diakses pada 5 Oktober 2013).
Suryabrata, Sumadi. 2007. Psikologi Pendidikan. Jakarta : PT. Raja Grafindo Persada.

Syah, Muhibbin. 2004. Psikologi Belajar. Jakarta : PT. Raja Grafindo Persada.

Taufik Efendy, Muhammad. 2010. Pengaruh Kompetensi, Independensi, dan Motivasi Terhadap Kualitas Audit Aparat Inspektorat Dalam Pengawasan Keuangan Daerah. Tersedia pada

http://eprints.undip.ac.id/24634/1/ Muh._Taufiq_Efendy.pdf (diakses pada 1 September 2013).

Umar, Husein. 2008. Desain Penelitian Kualitatif dan Kuantitatif. Jakarta: PT Raja Grafindo Persada

Wahyono, Teguh. 2009. 25 Model Analisis Statistik dengan SPSS 16. Jakarta : PT Elex Media Komputindo 